\title{
Needle sticks and sharps injuries experienced by staff nurses and nursing students and their prevention
}

\author{
Ruta Lukianskyte ${ }^{1,2}$, Julija Gataeva ${ }^{2}$, Laimute Radziunaite ${ }^{1}$ \\ ${ }^{1}$ Republic Hospital of Kaunas, Lithuania \\ ${ }^{2}$ Kauno Kolegija/Kaunas University of Applied Sciences, Lithuania
}

doi: 10.3396/ijic.v8i1.002.12

\begin{abstract}
The object of this study was to determine the frequency of needle sticks and sharps injuries (NSIs), to assess and compare the reasons and factors affecting NSIs experienced by staff nurses and nursing students and to define how they were informed about notification and prevention of NSIs.
\end{abstract}

In 2010 staff nurses and nursing students performing invasive injections at the Republic Hospital of Kaunas participated in the survey. Two hundred fifty questionnaires were distributed, of which 196 were returned giving a response rate of $78.4 \%$.

During the 12-month study period, NSIs were experienced by $38.5 \%$ of staff nurses and $78 \%$ of nursing students. Activities occurring in procedure rooms presented the highest risk of experiencing a needle stick or sharps injury.

For nurses, fifty-one percent (51\%) sustained their injuries when putting a case on a used needle (recapping). Forty-nine percent (49\%) of the nursing students experienced an injury when breaking an ampoule. Prevailing reasons for injuries were inattentiveness, being in a hurry and work overload.

More of the staff nurses (96.9\%) than the nursing students ( $40 \%$ ) were familiar with the rules of NSIs notification, registration, observation and prevention. Among staff nurses, $45.9 \%$ of the occurrences were unreported while for nursing students $92.0 \%$ were unreported.

\section{Corresponding author}

Ruta Lukianskyte

Republic Hospital of Kaunas, Hipodromo 13, Kaunas, LT - 45130, Lithuania

Email: rutalu@gmail.com 
Only $16.9 \%$ of staff nurses and $11 \%$ of nursing students were vaccinated with three doses of HBV vaccine. This study showed that more attention should be given to notification of needle stick and sharps injuries among nursing students. Immunization of staff nurses and nursing students with hepatitis B vaccine should also be encourage and recommended.

\section{Key words}

NEEDLESTICK INJURIES; NEEDLESTICK INJURIES- prevention and control; STUDENTS, NURSING; NURSES

\section{Introduction}

Needle stick and sharp injuries (NSIs) can cause a significant risk to health care workers and are a threat to medical and nursing students. ${ }^{1,2}$ According to data from the World Health Organization (WHO), 35.7 million health care workers in the world are exposed to the risk of NSIs. Various literature data show that nurses experienced NSIs more frequently than other healthcare workers (HCWs). Depending on the country and hospital, the incident rate ranged from $27.4 \%$ to $66.2 \% .^{3-9}$

Medical and nursing students are an important group of health care providers. Medical students are at a particularly high risk for NSIs, because of their relative inexperience. $^{10}$ Occupational exposures, during undergraduate medical school, may involve between $11 \%$ and $50 \%$ of the students. ${ }^{1,2,9,11-14}$

In Lithuania, the occurrence of needle stick and sharps injuries are similar to other parts of the world. According to data from different sources, threequarters of survey participants noted that they had experienced a needle stick or sharps injury at work. The most frequently injured were the nurses. ${ }^{15-17}$

Any healthcare worker handling sharp devices is at risk of an occupational exposure to blood borne pathogens. ${ }^{18}$ Tarantola and other authors collected data from various sources of literature and determined that for HCWs there were 60 species of dangerous pathogens. ${ }^{19} \quad$ Many of these pathogens can be transmitted to HCWs through injuries. Blood-borne pathogens, such as human immunodeficiency virus (HIV), hepatitis B virus (HBV) and hepatitis $C$ virus (HCV) have been identified as the most common pathogens in occupational transmission. ${ }^{20}$ Certain groups of individuals are at greater risk than others, because of the nature of their work. Nurses and medical students belong to this high risk group. ${ }^{18}$

In order to reduce amount of NSIs, different countries have organized prevention measures. In 1983, the U.S. Centers for Disease Control and Prevention (CDC) issued recommendations for needle stick safety. ${ }^{21} \mathrm{~A}$ few years later, the Occupational Safety and Health Organization (OSHA) recognized the risks associated with needle stick and sharps injuries and in 1991 released a blood-borne pathogens standard. ${ }^{22}$

In 1991, Dr. Janine Jagger and her colleagues created and developed the EPINet (Exposure Prevention Information Network) surveillance system for healthcare facilities to standardize the tracking of needlestick injuries and blood exposures. Since 1992, more than 1,500 U.S. hospitals have adopted this EPINet program. Other countries, such as Canada, Italy, Spain, Japan and Great Britain also use this program for tracking NSIs.

Most literature sources indicated the use of safe medical devices as one of the most important steps to prevent NSIs. ${ }^{5,23,24}$ The use of such safety tools, even if used only 80 percent of the time, can reduce the number of sharps injuries. ${ }^{25}$

In Lithuania, the use of safe medical devices has been applied in a few prevention programs in order to improve occupational health and safety. ${ }^{15,17}$ But there is still insufficient attention paid to the prevention of NSIs for students training in hospitals.

The object of this study was to determine the frequency of needle stick and sharps injuries (NSIs), to assess and compare the reasons and factors affecting NSIs experienced by staff nurses and nursing students and 
to define how they are informed about notification and prevention of NSIs.

\section{Methods}

In 2010 staff nurses and nursing students performing invasive injections at the Republic Hospital of Kaunas participated in the survey. Nursing students from the second to their fourth year had their practice at this hospital. The survey was carried out using a questionnaire based methodology. The questionnaire was anonymous.

The definitions for a needle stick and a sharps injury were provided to the participants. The aims of study, the importance of correct answers and the confidentiality of study were highlighted. Ethical approval was obtained prior to beginning the study.

The questionnaire consisted of 30 questions divided into three parts. The first part presented sociodemographic questions. The second part had questions about the needle stick and sharps injuries at work, their frequency (including number, nature and reason), the place where the NSIs occurred and whether the event was reported. The third part listed questions about safety and health at work including HBV immunization status. A 12-month recall period was used throughout the questionnaire.
A total of 250 questionnaires were distributed. Respondents were interviewed in the workplace. The objective of the survey was explained to them and permission was received to use the obtained information. The time taken to complete the questionnaire was, on average, 15 minutes per person.

Data was analyzed using statistical software SPSS (Statistical Package for the Social Sciences) version 10.0. From the primary database, tables were composed for the responses to each question on the questionnaire. For each question, the number of responses submitted was calculated with their variation and percentage distribution. For questions that had more than one option for an answer, the distribution of the percentage was calculated for each response option.

\section{Results}

Of the 250 questionnaires, 196 were completed and returned (response rate $78.4 \%$ ) (Table I). Of the 196 people who responded to the questionnaire, $96(49.0 \%)$ were staff nurses and $100(51.0 \%)$ were nursing students who practiced at the hospital. All respondents in both groups were female. Among the staff nurses, the largest number of the respondents belonged to the 30-49 year group. Most of the nursing students were under thirty years old.

\begin{tabular}{|c|c|c|c|c|c|c|}
\hline \multirow[t]{2}{*}{ Factors } & \multicolumn{2}{|c|}{ Staff nurse } & \multicolumn{2}{|c|}{ Nursing student } & \multicolumn{2}{|r|}{ Total } \\
\hline & $\mathbf{n}$ & $\%$ & $\mathbf{n}$ & $\%$ & $\mathbf{n}$ & $\%$ \\
\hline Number of respondents* & 96 & 49.0 & 100 & 51.0 & 196 & 100 \\
\hline \multicolumn{7}{|l|}{$\operatorname{Age}^{* *}$} \\
\hline $18-25$ years & 0 & 0.0 & 64 & 64.0 & 64 & 32.6 \\
\hline $26-30$ years & 12 & 12.5 & 26 & 26.0 & 38 & 19.4 \\
\hline $31-40$ years & 26 & 27.1 & 10 & 10.0 & 36 & 18.4 \\
\hline $40-49$ years & 31 & 32.3 & 0 & 0.0 & 31 & 15.8 \\
\hline 50 and above & 27 & 28.1 & 0 & 0.0 & 27 & 13.8 \\
\hline
\end{tabular}

$\mathrm{n}=$ number of subjects; ${ }^{*}$ percent from total respondents; ${ }^{* *}$ percent from respondents of different groups 


\section{Table II. Characteristics of needlestick and sharp injuries}

\section{Factors}

Staff nurse Nursing student

NSIs number

\begin{tabular}{rrrr}
$\mathbf{n}$ & \% & $\mathbf{n}$ & $\mathbf{\%}$ \\
\hline 37 & 38.5 & 78 & 78.0
\end{tabular}

\section{Locations}

\begin{tabular}{lrrrr}
\hline Procedures room & 17 & 46.0 & 46 & 59.0 \\
\hline Patient room & 9 & 24.3 & 12 & 15.0 \\
\hline Survey room & 3 & 8.1 & 11 & 14.0 \\
\hline Operating room & 8 & 21.6 & 9 & 12.0 \\
\hline Procedure & & & & \\
\hline Recapping a needle & 19 & 51.0 & 14 & 18.0 \\
\hline Breaking ampoules & 0 & 0.0 & 39 & 49.0 \\
\hline During injection, puncture & 4 & 11.0 & 8 & 10.0 \\
\hline During the intervention by instrument & 4 & 11.0 & 0 & 0.0 \\
\hline Processing instruments & 4 & 11.0 & 15 & 19.0 \\
\hline During cleaning & 2 & 5.0 & 2 & 4.0 \\
\hline By disposing to the sharps container & 2 & 5.0 & 0 & 0.0 \\
\hline Handling the waste, which should not have sharp objects & 1 & 3.0 & 0 & 0.0 \\
\hline Other & 1 & 3.0 & 0 & 0 \\
\hline
\end{tabular}

\section{Factors}

\begin{tabular}{lrrrr}
\hline Heavy workload & 16 & 43.2 & 9 & 12.0 \\
\hline Lack of protection measures & 1 & 2.7 & 2 & 3.0 \\
\hline Inattention, haste & 17 & 45.9 & 50 & 64.0 \\
\hline Tiredness & 7 & 18.9 & 17 & 21.0 \\
\hline Other & 3 & 8.1 & 0 & 0.0 \\
\hline Protection & & & & \\
\hline No gloves & 9 & 24.3 & 23 & 29.0 \\
\hline Gloves & 27 & 73.0 & 55 & 71.0 \\
\hline Double gloves & 1 & 2.7 & 0 & 0.0 \\
\hline
\end{tabular}


A total of 115 NSIs were reported to have occurred during the 12 month survey period (Table II). Staff nurses reported $37 \mathrm{NSIs}$ events, which equaled $38.5 \%$ of the total incidents reported in this survey. Nursing students reported a total of 78 NSIs. Approximately half of all injuries in both groups of respondents occurred in the procedure rooms. Among staff nurses, most injuries involved recapping the needle (51\%). For student nurses, the most common injury occurred when breaking ampoules $(49.0 \%)$, followed by processing instruments (19.0\%) and recapping a needle (18.0\%).

Factors, which led to injuries mainly among staff nurses, were inattention or haste $(45.9 \%)$ and heavy workload (43.2\%). Among nursing students, the main factor which involved NSIs was inattention and haste $(45.9 \%)$. About $21 \%$ of the injuries were listed as being caused by tiredness. Most of respondents in both investigated groups were wearing gloves during procedures. But the study results showed that they did not used the double glove technique.

More of the staff nurses (96.9\%) than the nursing students $(40 \%)$ were familiar with the rules of NSIs notification, registration, observation and prevention. Unreported NSIs statistics are illustrated in Table III. For staff nurses, $45.9 \%$ of their injuries were not reported. Among nursing students, $92.0 \%$ were unreported. The reason was that the injured respondents did not think that it was important to report this event $38.0 \%$ and $69.0 \%$ respectively) (Table III).

Another problem was that nursing students did not know where the injuries should be reported and how to register them $(17.0 \%)$. Some of them were afraid to register the injury $(11.0 \%)$. Staff nurses noted that registration took a lot of time $(31.0 \%)$. Of the unreported cases, $16.0 \%$ were due to other reasons.

Only $16.9 \%$ of staff nurses and $11.0 \%$ of nursing students had received the full hepatitis $B$ vaccine series. About half of the nursing students had incomplete vaccination and $57.8 \%$ of the staff nurses were not vaccinated at all.

\section{Discussion}

This study showed that prevention of needle stick and sharps injuries is very important in the work place. Staff nurses reported 37 (38.5\%) NSIs events. Nursing students reported a $78 \%$ injury rate. More than threefourths $(78 \%)$ of the nursing students interviewed experienced NSIs.

Some authors noted that the frequency of injuries is higher among nursing students than staff nurses. ${ }^{26}$ The incidence of needle stick and sharp injuries among medical and nursing students varies between different countries. For example, nursing students had

Table III. Reason for non-reporting of NSIs

Factor

\begin{tabular}{rrrr}
\multicolumn{2}{c}{ Staff nurse } & \multicolumn{2}{c}{ Nursing student } \\
\hline $\mathbf{n}$ & \% & n & \% \\
\hline 17 & 45.9 & 72 & 92.0
\end{tabular}

Non-reporting

92.0

Reasons

\begin{tabular}{lrrrr}
\hline Did not think it is important & 6 & 38.0 & 50 & 69.0 \\
\hline Registration takes a lot of time & 5 & 31.0 & 2 & 3.0 \\
\hline Did not know where and how to register & 2 & 12.0 & 12 & 17.0 \\
\hline Afraid to register & 1 & 3.0 & 8 & 11.0 \\
\hline Other & 3 & 16.0 & 0 & 0.0 \\
\hline
\end{tabular}


Table IV. Immunization status

Factor

Staff nurse Nursing student

\begin{tabular}{llll}
\hline $\mathbf{n}$ & $\%$ & $\mathbf{n}$ & $\%$
\end{tabular}

\begin{tabular}{lllll}
\hline Full vaccination (3 doses) & 16 & 16.9 & 11 & 11.0 \\
\hline Incomplete vaccination & 24 & 25.3 & 49 & 49.0 \\
\hline Not vaccinated & 56 & 57.8 & 40 & 40.0 \\
\hline
\end{tabular}

the following NSIs incidence rates: Taiwan - 50.5\%; ${ }^{2}$ Uganda - $25.3 \%{ }^{27}$ and Australia - $13.9 \%{ }^{28}$ Medical students had the following NSIs incidence rates: Iran - 73.4\%, ${ }^{29}$ USA - 30-33\%, ${ }^{30}$ UAE - 23.0\%, ${ }^{14}$ Brazil $14 \%{ }^{9}$ and Germany $-12-41 \% .^{13}$

The authors of this study determined that due to the high number of needle stick and sharps injuries reported among the nursing students, there was a need for more effective training programs. The experience of other countries has indicated that such programs could significantly decrease the incidence of NSIs.,26

This study illustrated that about one half of all injuries in both groups of respondents occurred in the procedure room. Smith and Leggat noted that most NSIs for nursing students occurred in the nursing laboratory $(45 \%) .{ }^{28}$ However, many literature sources indicated that the NSIs occurred mainly in patient rooms and in the operating rooms, places where sharp instruments were frequently used. ${ }^{7,8,31}$

The most frequent injury for staff nurses involved the recapping of needles (51\%). This was also found to be the cause of NSIs in a variety of other studies by various authors. ${ }^{7,9,14,29}$ For nursing students in this study, breaking ampoules (49.0\%) was the most common cause of NSIs injuries.

Most of the respondents, in both investigated groups, were wearing gloves during procedures. This study showed that both groups usually did not use the double glove technique. Various published studies show that $50-74 \%$ of the medical and dental students did not use the double glove technique. ${ }^{29,32,33}$ The reason those students gave for not using double gloves was due to the decrease sense of touch and the lack of belief in its benefits. ${ }^{32,33}$ Yang and Mullan, in their review, underlined the benefit of double gloving for protection of NSIs. ${ }^{34}$

According to data from this study, $40 \%$ of the nursing students were familiar with the rules of NSIs notification, registration, observation and prevention, however, $92.0 \%$ of all NSIs among them were unreported, because they did not think that it was important. A high percent of non-reporting of NSIs among students is also a problem in other countries. ${ }^{1,2,14,18}$ Some authors noticed that training programs for medical and nursing students significantly decreased the amount of non-reported injuries. ${ }^{1,2}$

The study data illustrated that more attention should be paid to the registration of needle stick and sharps injuries among nursing students. It also indicated that the hepatitis B vaccination series for staff nurses and nursing students should be encouraged and recommended since it was shown that a low percentage of staff nurses and nursing students had received their complete series of hepatitis B vaccine.

\section{References}

1. Cervini P, Bell C. Brief report: Needlestick injury and inadequate post-exposure practice in medical students. / Gen Intern Med 2005; 20: 419-421. http://dx.doi.org/10.1111/ j.1525-1497.2005.0092.x

2. Yang $\mathrm{YH}$, Liou $\mathrm{SH}$, Chen $\mathrm{C}$, et al. The effectiveness of a training program on reducing needlestick injuries/sharp object injuries among soon graduated voacational nursing school students in southern Taiwan. J Occup Health 2007; 49: 424-429. http://dx.doi.org/10.1539/joh.49.424

3. EPINet data. http://www.healthsystem.virginia.edu/internet/ epinet/about_epinet.cfm. [Accessed January 1, 2008].

4. NaSH data. http://www.cdc.gov/ncidod/dhqp/nash.html [Accessed February 15, 2008]. 
5. Whitby RM, McLaws ML. Hollow-bore needlestick injuries in a tertiary teaching hospital: epidemiology, education and engineering. MJA 2002; 177: 418-422.

6. Ayranci U, Kosgeroglu N. Needlestick and sharps injuries among nurses in the healthcare sector in a city of western Turkey. J Hospital Infect 2004; 58: 216-223. http://dx.doi. org/10.1016/j.jhin.2004.06.029

7. Oha HS, Yib SE, Choec KW. Epidemiological characteristics of occupational blood exposures of healthcare workers in a university hospital in South Korea for 10 years. J Hospital Infect 2005; 60: 269-275. http://dx.doi.org/10.1016/j. jhin.2004.11.026

8. Sulsky SI, Cohen LC, Luippold RS, Heidenreich MJ, Nunes A. Effectiveness of measures to prevent needlestick injuries among employees in health professions. $2006.116 \mathrm{p}$.

9. Rapparini C, Saraceni V, Lauria LM, et al. Occupational exposures to bloodborne pathogens among healthcare workers in Rio de Janeiro, Brazil. J Hospital Infect 2007; 65: 131-137. http://dx.doi.org/10.1016/j.jhin.2006.09.027

10. Tereskerz PM, Pearson RD, Jagger J. Occupational exposure to blood among medical students. N Eng//Med 1996; 335: 1150 1153. http://dx.doi.org/10.1056/NEJM199610103351512

11. Osborn EH, Papadakis MA, Gerberding JL. Occupational exposures to body fluids among medical students. A sevenyear longitudinal study. Ann Intern Med 1999; 130: 45-51.

12. Schmid K, Schwager C, Drexler H. Needlestick injuries and other occupational exposures to body fluids amongst employees and medical students of a German university: incidence and follow-up. I Hospital Infect 2007; 65: 124130. http://dx.doi.org/10.1016/j.jhin.2006.10.002

13. Deisenhammer S, Radon K, Nowak D, Reichert J. Needlestick injuries during medical training. I Hospital Infect 2006; 63: 263-267. http://dx.doi.org/10.1016/j.jhin.2006.01.019

14. Jaber MA. A survey of needle stick and other sharp injuries among dental undergraduate students. Int I Infect Control 2011; 7(3): 1-10. http://dx.doi.org/10.3396/ijic.V7i3.022.11

15. Jakuš J. Sveikatos priežiūros ịstaigų darbuotojų profesinių infekcinių susirgimų profilaktika, 2004. www.svsc.It/archive/ programos/proghepatitas.html [Accessed April 25, 2008].

16. Rakickienè J. Sveikatos priežiūros darbuotojų profesinio užsikrètimo ŽIV rizika ir specifinè profilaktika. Slauga 2003; 2: 10-14.

17. Ščeponavičius A, Ivanauskienė O, Šarkinienè J. Mikrotraumos ir jų prevencija gydymo istaigose. Lietuvos higienistu ir epidemiologu suvažiavimo medžiaga. 2003; 16.

18. Lee LK, Noor Hassim I. Implication of the prevalence of needlestick injuries in a general hospital in Malaysia and its risk in clinical practice. Environ Health Prev Med 2005; 10: 33-41. http://dx.doi.org/10.1265/ehpm.10.33
19. Tarantola A, Abiteboul D, Rachlinec A. Infection risks following accidental exposure to blood or body fluids in health care workers: A review of pathogens transmitted in published cases. A/IC 2006; 34(6): 367-375.

20. Prüss-Üstün A, Rapiti E, Hutin Y. Sharp injuries: global burden of disease from sharps injuries to health-care workers. Geneva: World Health Organization. 2003; 3.

21. May D, Brewer S. Sharps injury: prevention and management. Nurs Stand 2001; 15(32): 45-52.

22. Tan L, Hawk JC, Sterling ML. Report of the council on scientific affairs: preventing needlestick injuries in health care settings. Arch Intern Med 2001; 161(7): 929-936. http:// dx.doi.org/10.1001/archinte.161.7.929

23. Adams D, Elliott TSJ. Impact of safety needle devices on occupationally acquired needlestick injuries: a four-year prospective study. J Hospital Infect 2006; 64: 50-55. http:// dx.doi.org/10.1016/j.jhin.2006.04.012

24. Lamontagne F, Abiteboul D, Lolom I, et al. Role of safetyengineered devices in preventing needlestick injuries in 32 French hospitals. Infect Control Hospital Epidem 2007; 28(1): 18-23. http://dx.doi.org/10.1086/510814

25. Stoker R. Needlestick prevention. US Nursing Leadership. 2006: 11-12.

26. Yang YH, Wu MT, Ho CK, et al. Needlestick/sharps injuries among vocational school nursing students in southern Taiwan. Am J Infect Control 2004; 32: 431-435. http://dx.doi. org/10.1016/j.ajic.2004.02.007

27. Hulme P. Incidence of needlestick injuries among Ugandan student nurses in a rural hospital. Rural and Remote Health 2009; 9: 1185.

28. Smith DR, Leggat PA. Needlestick and sharps injuries among nursing students. J Advan Nursing 2005; 51(5): 449-455. http://dx.doi.org/10.1111/j.1365-2648.2005.03526.x

29. Hashemipour M, Sadeghi A. Needlestick injuries among medical and dental students at the University of Kerman. A questionnaire study. SID 2008; 5(2): 71-76.

30. Patterson JMM, Novak CB, Mackinnon SE, Ellis RA. Needlestick injuries among medical students. Am J Infec Control 2003; 31: 226-230. http://dx.doi.org/10.1067/mic.2003.44

31. Moens G, Mylle G, Johannik Van Hoof A, Helsen G. Analysing and interpreting routinely collected data on sharps injuries in assessing preventative actions. Occupational Medicine 2004; 54(4): 245-249. http://dx.doi.org/10.1093/occmed/kqh041

32. Norsayani MY, Noor Hassim I. Study on incidente of needle stick injury and factors associated with this problem among medical students. J Occup Health 2003; 45(3): 172-178. http://dx.doi.org/10.1539/joh.45.172

33. Meunier O, Almeida N, Hernandez C, Bientz M. Blood exposure accidents among medical students. Médecine et maladies infecc 2001; 31(9): 537-543.

34. Yang L, Mullan B. Reducing needle stick injuries in healthcare occupations: an integrative review of the literature. ISRN Nursing 2011; Article ID 315432, 11. 